\title{
Biodegradable Bags for the Production of Plant Seedlings
}

\author{
Ana Paula Bilck, Juliana Bonametti Olivato, Fabio Yamashita \\ Departamento de Ciência e Tecnologia de Alimentos, Universidade Estadual de Londrina - UEL \\ José Roberto Pinto de Souza \\ Departamento de Agronomia, Universidade Estadual de Londrina - UEL
}

\begin{abstract}
The production of plant seedlings has traditionally used polyethylene bags, which are thrown out in the soil or burned after transplant because the large amount of organic material attached to the bags makes recycling difficult. Additionally, when a seedling is taken from the bag for transplant, there is the risk of root damage, which compromises the plant's development. In this study, we developed biodegradable bags to be used in seedling production, and we verify their influence on the development of Brazilian ginseng (Pfaffia glomerata (Spreng) Pedersen), when the plant is planted without being removed from the bag. Both black and white biodegradable bags remained intact throughout the seedling production period (60 days). After being transplanted into containers ( 240 days), they were completely biodegraded, and there was no significant difference between the dry mass of these plants and that of plants that were transplanted without the bags. The plants that were cultivated without being removed from the polyethylene bags had root development difficulties, and the wrapping showed no signs of degradation. The use of biodegradable films is an alternative for the production of bags for seedlings, as these can then be transplanted directly into the soil without removing the bag, reducing the risk of damage to the roots during the moment of transplant.
\end{abstract}

Keywords: Blow extrusion, polyethylene bags, biodegradable polymer, Brazilian ginseng, Pfaffia glomerata (Spreng) Pedersen.

\section{Introduction}

In recent years, there has been increased interest in the use of biodegradable polymers to minimize the environmental problems caused by the disposal of traditional synthetic polymers ${ }^{[1]}$. Materials composed of biodegradable polyester from renewable or fossil resources, or a combination of both, like Ecobras ${ }^{\mathrm{TM}}$ (BASF, Germany), are being studied an alternative to the substitute the traditional synthetic polymers that are used in agriculture, such as mulch film, bags, low tunnels and greenhouses. These materials are susceptible to various forms of degradation (thermal, oxidative, mechanical, or biological) after being exposed to the environment ${ }^{[1-3]}$.

Low density polyethylene bags, which are usually black, are used for seedling production. In Brazil, there have been no studies of the forms of disposal of these bags or of their final destination after use and seedling planting. However, by the volume of seedlings cultivated, the amount of plastic used is by no means negligible. In Europe, only a portion of the plastic materials that are used in agriculture is recycled, with the majority being left in the soil, causing irreversible contamination, or being incinerated, releasing harmful substances into the air. These procedures occur because of the high cost of labor for the proper removal of these films after application and the lack of an economically viable disposal system ${ }^{[4]}$. Another problem is that the films are difficult to recycle due to the high amount of organic matter that adheres to the material.

This study aimed at producing biodegradable films by extrusion, with adequate properties to be used in the production of bags for seedlings. The developed bags were tested in the production of Pfaffia seedlings, known as suma root, Pantanal ginseng or Brazilian ginseng.

Species of the genus Pfaffia are being studied due to the medicinal properties of the substances that are present in their roots. The roots of Pfaffia glomerata (Spreng) Pedersen, as well as those of Pfaffia paniculata Kuntze, are commercially important as phyto-medicine and nutritional supplements because of their popular use $\mathrm{e}^{[5]}$.

\section{Materials}

Native starch from cassava (Indemil, Brazil) and commercial glycerol (Dinamica, Brazil) were used to produce thermoplastic starch. The biodegradable polymer used was poly (butylene adipate-co-terephthalate) (PBAT), manufactured by Basf (Germany) under the commercial name of Ecoflex ${ }^{\circledR} 7011$; for black films, the pigment Sicopal Black ${ }^{\circledR}$ K0095, also from Basf (Germany) was used.

Black low-density polyethylene bags for seedlings (PE) were purchased from Agro-Plast (Brazil) and used as controls.

\section{Experimental}

\section{Preparation of biodegradable films}

The film was produced by blown extrusion using a pilot extruder, BGM EL-25 (Brazil), which is made up of a $25 \mathrm{~mm}$ diameter screw, a 10-HP motor drive, four 
heating zones and an external cooling air ring with a 300- to 350-mm diameter.

The thermoplastic starch $(\mathrm{TpS})$ was produced by mixing cassava starch with glycerol $(75: 25 \mathrm{w}: \mathrm{w})$. This mixture was extruded, pelletized, and mixed with PBAT (30 TpS: 70 PBAT w:w) to produce the white biodegradable film (WBF). For the black biodegradable film (BBF), $2 \%$ pigment was added to the TpS+PBAT mixture. The blend pellets were extruded twice and then processed to form the film by blow extrusion.

To prepare the bags for the seedlings, WBF and BBF with widths of $80( \pm 7)$ and $88( \pm 9) \mu \mathrm{m}$, respectively, were cut crosswise with a height of $16( \pm 0.5) \mathrm{cm}$ and a width of $10.5( \pm 0.5) \mathrm{cm}$ and thermosoldered to the ends in a Micromatic automatic heat sealer (Brazil) at a temperature of $130{ }^{\circ} \mathrm{C}$ for 5 seconds. Next, the bags were perforated on each side with six $0.6-\mathrm{cm}$-wide holes, using punch pliers so that the bags were identical to the polyethylene (PE) seedling bags.

\section{Film characterization}

\section{Mechanical properties of the films}

The mechanical properties of the films were assessed in a Stable Micro Systems texturometer model TA-TX2i (England) according to the methodology established by the American Society for Testing and Material ASTM D882-00 ${ }^{[6]}$. The maximum tensile strength (MPa), elongation at break (\%) and Young's or elasticity modulus $(\mathrm{MPa})$ were assessed.

\section{Visual inspection of the films}

The biodegradation of the seedling sacs was registered and recorded with a Samsung S730 7.2 megapixel camera (Samsung Techwin CO Ltd, Korea). The pictures were organized in chronological order for visual evaluation of the degradation of the films over time.

\section{Planting of the Brazilian ginseng cuttings in the seedling bags}

The Brazilian ginseng (Pfaffia glomerata (Spreng) Pedersen) seedlings, which came from the State University of Londrina collection, were produced from cuttings and were transferred to polyethylene bags (PE), white biodegradable bags (FBB), or black biodegradable bags (FBP) with one of three allotments of the commercial substrate Triângulo (Brazil) and carbonized rice hulls: S1 (40:60) $\left(28.4 \mathrm{~g} / \mathrm{dm}^{3}\right.$ organic material; $1.42 \mathrm{~g} / \mathrm{dm}^{3}$ nitrogen; $61.4 \mathrm{~g} / \mathrm{dm}^{3}$ phosphorous; $2.05 \mathrm{~g} / \mathrm{dm}^{3}$ potassium; pH 6.11 and acidity 2.45); S2 (50:50) (21.7 g/dm ${ }^{3}$ organic material; $1.08 \mathrm{~g} / \mathrm{dm}^{3}$ nitrogen; $71.23 \mathrm{~g} / \mathrm{dm}^{3}$ phosphorous; $2.05 \mathrm{~g} / \mathrm{dm}^{3}$ potassium; $\mathrm{pH} 6.09$ and acidity 2.50 ), and $\mathbf{S 3}$ $(60: 40)\left(33.14 \mathrm{~g} / \mathrm{dm}^{3}\right.$ organic material; $1.66 \mathrm{~g} / \mathrm{dm}^{3}$ nitrogen; $139.07 \mathrm{~g} / \mathrm{dm}^{3}$ phosphorous; $2.82 \mathrm{~g} / \mathrm{dm}^{3}$ potassium; $\mathrm{pH} 6.53$ and acidity 2.34 ).

The seedlings were incubated in a greenhouse at the State University of Londrina (latitude $23^{\circ} 22^{\prime} \mathrm{S}$, longitude $51^{\circ} 10^{\prime} \mathrm{W}$, and altitude $585 \mathrm{~m}$ ) for 60 days and were watered daily with $75 \mathrm{~mL}$ of water. The relative humidity $(\mathrm{RH})$ and temperature (T) were recorded daily ( $\mathrm{RH}$ of $42 \%$ to $95.5 \%$ and $\mathrm{T}$ of $19.9^{\circ} \mathrm{C}$ to $\left.33.5^{\circ} \mathrm{C}\right)$. The experimental design was random blocks, with 6 treatments ( 3 bags and 3 substrates); each treatment was replicated 5 times, and collections were conducted every 30 and 60 days. Height was measured with a tape measure and the total dry mass was measured with an oven at $60{ }^{\circ} \mathrm{C}^{[7]}$.

\section{Planting of the Brazilian ginseng plants in containers}

After they were grown in the bags (item 3.3), the Brazilian ginseng seedlings were transplanted into $3.5 \mathrm{~kg}$ polyethylene containers with red clayey Oxisol soil that was fertilized with $10 \mathrm{~g}$ granulized commercial Cargill (Brazil) NPK (8:28:16) fertilizer. The composition of the fertilized soil was $54.05 \mathrm{~g} / \mathrm{dm}^{3}$ organic material; $2.70 \mathrm{~g} / \mathrm{dm}^{3}$ nitrogen; $573.25 \mathrm{~g} / \mathrm{dm}^{3}$ phosphorous; and $0.79 \mathrm{~g} / \mathrm{dm}^{3}$ potassium, with pH 6.53 and acidity 3.02. The experimental design was randomized blocks, with 6 treatments: 3 different bags for seedlings (WBF, BBP and PE) and 3 ways of planting the seedlings (with the entire bag, with the bottom cut off and without the bag), with 10 repetitions for each treatment.

The containers of Brazilian ginseng were incubated in the greenhouse at the State University of Londrina for 240 days with daily watering that maintained the relative humidity of the soil at approximately $65 \%( \pm 5)$. Collections were done every 60, 120 and 240 days, with the dry mass of the roots being determined in a $60^{\circ} \mathrm{C}$ oven ${ }^{[6]}$, and a visual inspection of the seedling bags in the containers was performed. After 100 days of growth, the plants received $3 \mathrm{~g}$ of a granulated commercial fertilizer, Cargill (Brazil) NPK (8:28:16). The relative humidity and temperature were recorded daily, with the average low relative humidity at $54.8 \%$ and the maximum relative humidity at $90.8 \%$; the average low temperature was $30.1^{\circ} \mathrm{C}$ and the average high temperature was $30.1^{\circ} \mathrm{C}$.

\section{Statistical analysis}

The data were subjected to variance analysis and Tukey's test for the comparison of means with Statistica software version 7.0 (StatSoft, Inc. Tulsa, OK) at the 5\% significance level.

\section{Results and Discussion}

\section{Mechanical properties of the films}

The mechanical properties of the maximum tensile strength, the elongation at break and Young's modulus for the biodegradable films before planting (time zero) can be observed in Table 1.

Regarding the maximum tensile strength, the elongation at break and Young's modulus, there was no difference between the films before planting $(\mathrm{p}<0.05 \%)^{[8]}$ produced black and white PBAT films with $30 \%$ ATp with a maximum tensile strength of 8.4 and $6.1 \mathrm{MPa} ; 537$ and $530 \%$ elongation at break and a Young's modulus of 48.6 and 40.1 MPa for the white and black films, respectively. 
Scapim ${ }^{[9]}$ produced biodegradable films by extrusion with 30\% ATp and 70\% PBAT and obtained maximum tensile strength values of approximately $10.5 \mathrm{MPa}$, an elongation at break of $700 \%$ and a Young's modulus of $20 \mathrm{MPa}$.

The mechanical properties of the films at 30 days after planting can be seen in Table 2 .

There was no significant difference between the maximum tensile strength and Young's modulus between the white and black films in the different substrates (S1, S2, and S3). The elongation in break was greater for the WBF3 (195\%) and lesser for the WBF1 (101\%).

When comparing Tables 1 and 2, it is possible to observe a $50 \%$ reduction in the maximum tensile strength and a $76 \%$ reduction in the elongation at break after 30 days for all substrates. Although there was a reduction in the mechanical properties of the films, the same films remained intact and without tears, even becoming more rigid when compared with time zero. Young's modulus increased approximately $45 \%$, confirming the increased stiffness of the films. Fluctuations in the temperature, humidity and solar radiation were the principal factors that were responsible for the loss of mechanical resistance and the increase in stiffness of the films, most likely due to photodegradation that was caused by being exposed to ambient light and the formation of crosslinks. According to Kijchavengkul ${ }^{[3]}$, the carbonyl chromophoric group that is present in biodegradable polyesters is the most susceptible to photodegradation. According to Chandra and Rustgi ${ }^{[10]}$, the presence of ultraviolet light can cause oxidation, reducing the stability of the films.

\section{Development of the Brazilian ginseng seedlings}

After 30 days (Figure 1a), the average heights of the Brazilian ginseng seedlings grown in the BBF and WBF bags varied from 8.5 to $12 \mathrm{~cm}$ and were not significantly different from those that were grown in the polyethylene bags (PE), independent of the substrate used. Plant height was also not influenced by the different substrates, either for $\mathrm{S} 1$ (40\% commercial substrate) or S3 (60\% commercial substrate), and the development of the seedlings related to the height was very similar. According to Vidal et al. ${ }^{[1]}$, the Mikania glomerata cuttings developed on substrates with different concentrations of vermiculite did not show significant differences among the parameters evaluated, indicating that for some species the variation in the substrate does not influence the development of the plant.

After 30 days, there was no difference between the average dry mass of the seedlings grown in the BBF, WBF and PE bags or between substrates. The average dry mass of all of the treatments was $0.082( \pm 0.01)$ g.plant $t^{-1}$.

The development of the Brazilian ginseng seedlings in the 60-day period can be observed in Figures 1c and d. The average height of the seedlings that were cultivated in the PE, BBF and WBF bags did not differ, with an average value of $68.8( \pm 7.9) \mathrm{cm}$.

After 60 days, the average dry mass of the seedlings that were cultivated in the WBF, BBF and PE bags did not differ. There was also no difference between the substrates and the average value of the dry mass, which for all treatments was $1.2( \pm 0.4)$ g.plant ${ }^{-1}$.

The use of seedling bags made of BBF or WBF did not influence the development of the Brazilian ginseng plants during the period between 30 and 60 days as compared with bags made of PE. The biodegradable bags were more fragile and rigid but remained intact to handle the seedlings (Figure 2).

\section{Development of the Brazilian ginseng seedlings and biodegradation of the $W B F, B B F$ and $P E$ bags during the periods of 60,120 , and 240 days}

The Brazilian ginseng seedlings were collected at 60 , 120 , and 240 days after planting in the containers for the

Table 1. Mechanical properties of the films before seedling planting (time zero).

\begin{tabular}{cccc}
\hline Film & $\begin{array}{c}\text { Maximum tensile strength } \\
(\mathbf{M P a})\end{array}$ & $\begin{array}{c}\text { Elongation at break } \\
(\%)\end{array}$ & $\begin{array}{c}\text { Young's modulus } \\
(\mathbf{M P a})\end{array}$ \\
\hline WBF & $13.2^{\mathrm{a}}( \pm 1.3)$ & $656^{\mathrm{a}}( \pm 55)$ & $56^{\mathrm{a}}( \pm 6)$ \\
BBF & $12.4^{\mathrm{a}}( \pm 0.8)$ & $641^{\mathrm{a}}( \pm 21)$ & $61^{\mathrm{a}}( \pm 7)$ \\
\hline
\end{tabular}

a,b Averages with different letters in the same column indicate a statistically significant difference at the 0.05 level by the Tukey test. White biodegradable film (WBF); Black biodegradable film (BBF).

Table 2. Mechanical Properties of the films 30 days after seedling planting.

\begin{tabular}{cccc}
\hline Film & $\begin{array}{c}\text { Maximum tensile strength } \\
(\mathbf{M P a})\end{array}$ & $\begin{array}{c}\text { Elongation at break } \\
(\%)\end{array}$ & $\begin{array}{c}\text { Young's modulus } \\
(\mathbf{M P a})\end{array}$ \\
\hline WBF1 & $4.7^{\mathrm{a}} \pm(0.8)$ & $99^{\mathrm{b}} \pm(10)$ & $89^{\mathrm{a}} \pm(20)$ \\
WBF2 & $5.9^{\mathrm{a}} \pm(0.9)$ & $101^{\mathrm{b}} \pm(39)$ & $97^{\mathrm{a}} \pm(11)$ \\
WBF3 & $5.6^{\mathrm{a}} \pm(0.9)$ & $195^{\mathrm{a}} \pm(25)$ & $87^{\mathrm{a}} \pm(7,9)$ \\
BBF1 & $5.6^{\mathrm{a}} \pm(1.8)$ & $132^{\mathrm{a}, \mathrm{b}} \pm(38)$ & $104^{\mathrm{a}} \pm(34)$ \\
BBF2 & $6.2^{\mathrm{a}} \pm(1.5)$ & $159^{\mathrm{a}, \mathrm{b}} \pm(67)$ & $120^{\mathrm{a}} \pm(17)$ \\
BBF3 & $5.9^{\mathrm{a}} \pm(0.6)$ & $183^{\mathrm{a}} \pm(45)$ & $113^{\mathrm{a}} \pm(12)$ \\
\hline
\end{tabular}

${ }^{a, b}$ Averages with different letters in the same column indicate a statistically significant difference at the 0.05 level by the Tukey test. White biodegradable film substrate 1 (WBF1); White biodegradable film substrate 2 (WBF2); White biodegradable film substrate 3 (WBF3); Black biodegradable film substrate 1 (BBF1); Black biodegradable film substrate 2 (BBF2); Black biodegradable film substrate 3 (BBF3). 

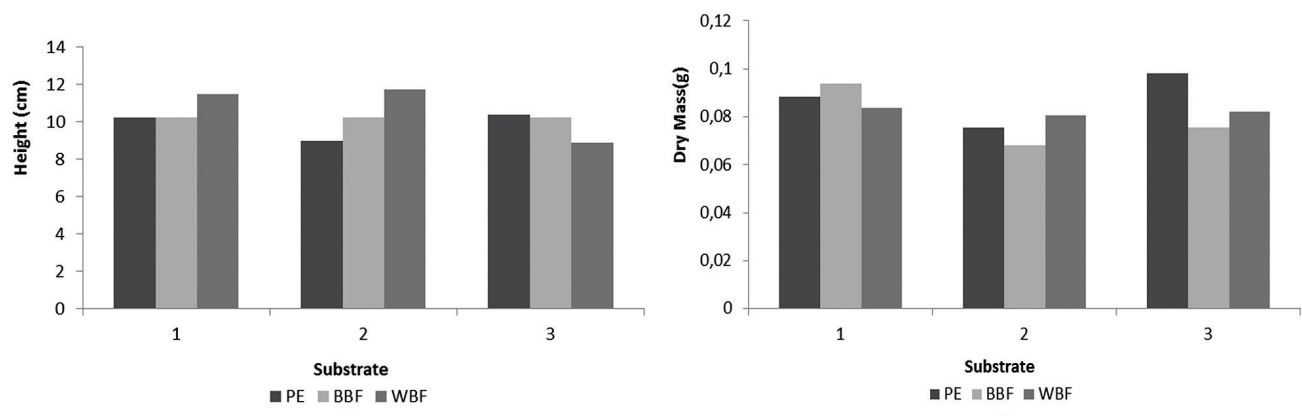

(a)
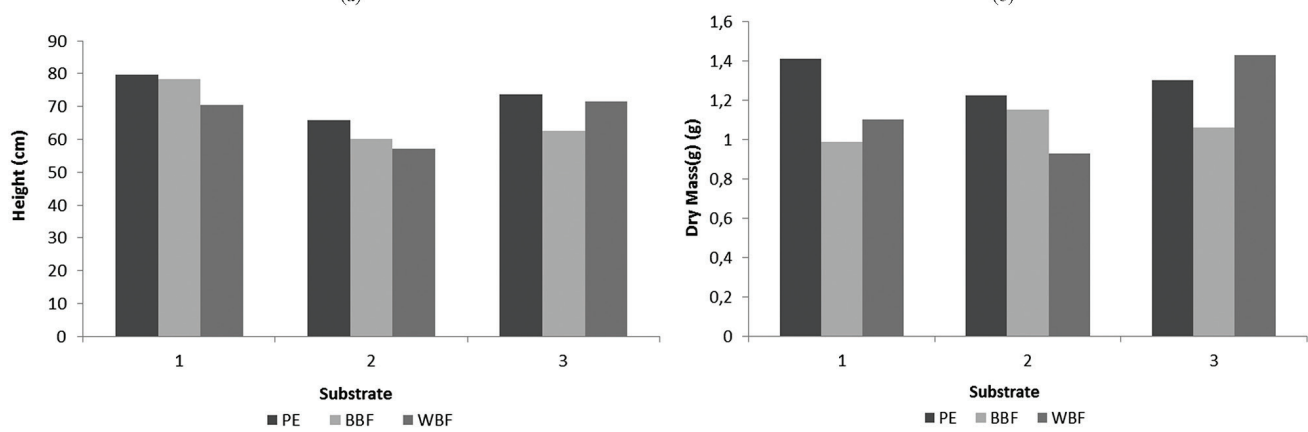

(c)

(d)

Figure 1. Average height and dry mass of the Brazilian ginseng seedlings grown in seedling bags of PE, BBF and WBF in substrates $\mathrm{S} 1, \mathrm{~S} 2$, and S3 after 30 days (a, b) and after 60 days (c, d). White biodegradable film (WBF); Black biodegradable film (BBF); Substrate 1 (S1); Substrate 2 (S2): Substrate 3 (S3).

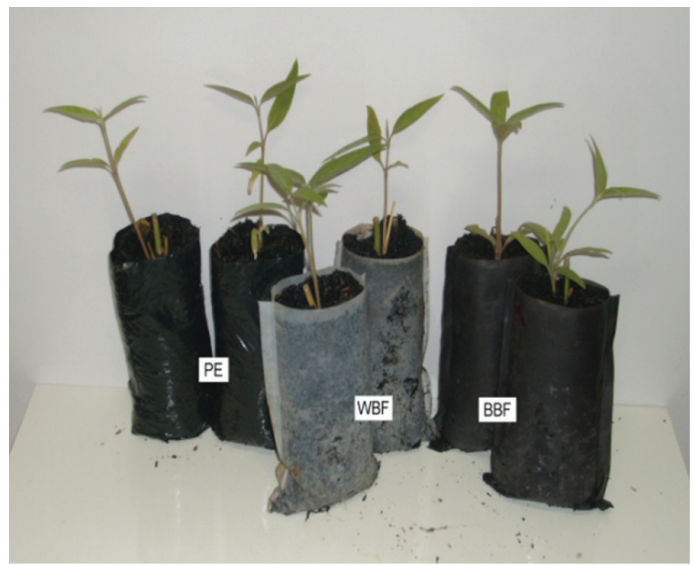

(a)

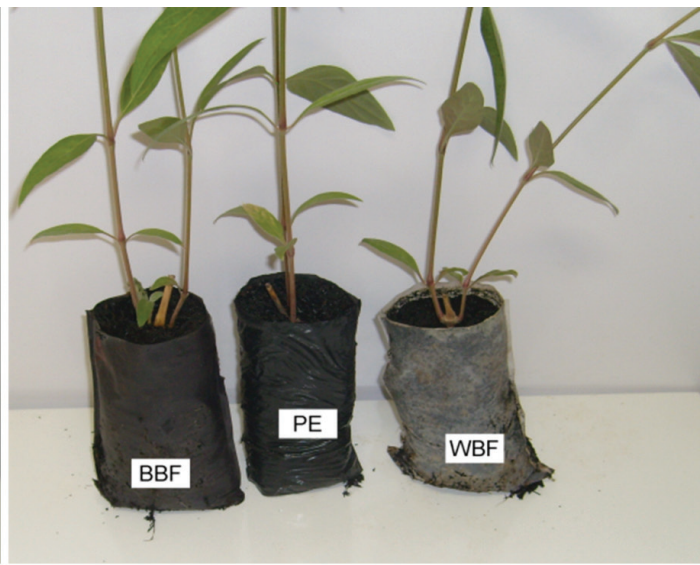

(b)

Figure 2. Brazilian ginseng seedlings 30 days after planting in PE, WBF and BBF bags (a); Brazilian ginseng seedlings 60 days after planting in BBF, PE and WBF bags (b).

three treatments (with the entire bag, with the bottom cut off and without the bag). The dry mass of the roots of the plants was measured, and a visual inspection of the biodegradation of the films was performed.

Sixty days after planting, the seedlings that had been planted with the whole WBF and BBF bags did not show a significant difference in their dry mass when compared to the seedlings that were transplanted without the bag or with the bottom cut off (Table 3 ).

The dry mass of the seedlings that were transplanted without the BBF bag was greater than that of the entire
BBF with the bottom cut off, where the value was 10.7 , 8.4, and 6.8 g.plant $^{-1}$, respectively. The seedlings that were planted in the BBF bags and were buried without wrapping had a higher dry mass (10.7 g.plant $\left.{ }^{-1}\right)$ than did those that were buried in the PE bags (6.2 g.plant $\left.{ }^{-1}\right)$ or WBF bags (6.8 g.plant $\left.{ }^{-1}\right)$.

The seedlings that were buried with the WBF or BBF bags did not show atrophied roots when compared to the plants that were grown in the PE bags, as can be observed in Figure 3. In the whole PE bags, the roots were enveloped, and some had already perforated the wrapping in search of space and soil nutrients. 
Table 3. Average dry mass of Brazilian ginseng roots 60 days after transplant to the containers.

\begin{tabular}{cccc}
\hline \multirow{2}{*}{ Film } & \multicolumn{3}{c}{ Dry mass (g.plant ${ }^{-1}$ ) } \\
\cline { 2 - 4 } & No bag & Bottom cut off & Whole bag \\
\hline WBF & $6.8^{\mathrm{a}, \mathrm{B}} \pm(2.0)$ & $7.9^{\mathrm{a}, \mathrm{A}} \pm(2.1)$ & $7.1^{\mathrm{a}, \mathrm{A}} \pm(0.5)$ \\
BBF & $10.7^{\mathrm{a}, \mathrm{A}} \pm(0.8)$ & $8.4^{\mathrm{a}, \mathrm{A}} \pm(1.6)$ & $6.8^{\mathrm{b}, \mathrm{A}} \pm(1.7)$ \\
PE & $6.2^{\mathrm{a}, \mathrm{B}} \pm(1.0)$ & $7.7^{\mathrm{a}, \mathrm{A}} \pm(2.3)$ & $7.5^{\mathrm{a}, \mathrm{A}} \pm(1.5)$ \\
\hline
\end{tabular}

${ }_{\mathrm{a}, \mathrm{b}}$ Averages with different letters in the same line indicate a statistically significant difference at the 0.05 level by the Tukey test. ${ }^{\mathrm{A}, \mathrm{B}}$ Averages with different letters in the same column indicate a statistically significant difference at the 0.05 level by the Tukey test. White biodegradable film (WBF); Black biodegradable film (BBF).

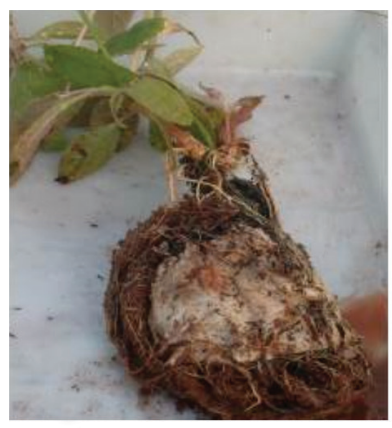

(a)

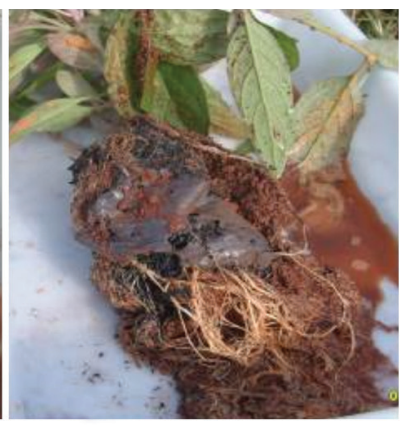

(b)

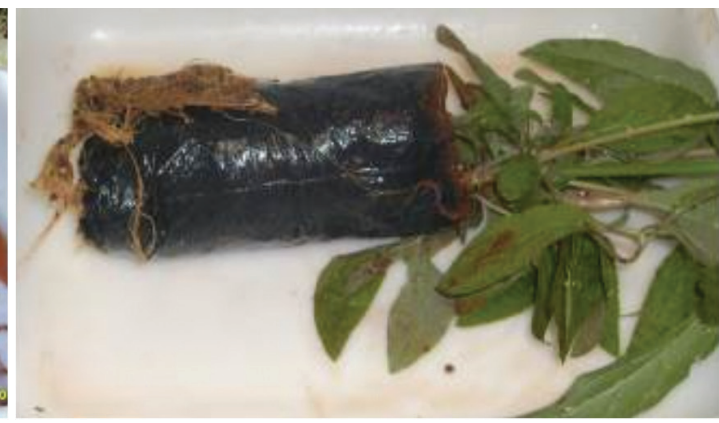

(c)

Figure 3. Visual evaluation of the biodegradation of WBF (a), BBF (b), and PE (c) bags 60 days after planting in containers. White biodegradable film (WBF); Black biodegradable film (BBF).

The biodegradation of the bags made of WBF, BBF and $\mathrm{PE}$ after 60 days from transplanting can be seen in Figure 3. The whole BBF and WBF bags showed approximately $40 \%$ of their original structure and disintegrated upon contact with water when the roots were washed.

The PE bags were complete and lacked any signs of decomposition or tearing, with only a few holes that were caused by root growth. Tena-Salcido et al. ${ }^{[12]}$ studied the biodegradation of blends of ATp and PEBD in activated mud during a 45-day period and found that the pure PEBD films did not lose mass, whereas the blends with $32 \%$ and $68 \%$ ATp lost 39 and $92 \%$ mass, respectively.

Such as temperature, humidity, aeration, nutrients, $\mathrm{pH}$, and osmotic pressure such as temperature, humidity, aeration, nutrients, $\mathrm{pH}$, and osmotic pressure such as temperature, humidity, aeration, nutrients, $\mathrm{pH}$, and osmotic pressure. The loss of mass in the polymeric films in the soil is affected by environmental conditions, such as temperature, humidity, aeration, nutrients, $\mathrm{pH}$, and osmotic pressure as well as structural characteristics of the polymer, such as molar mass, lateral ramifications, polarity, crystallinity, and the metabolic potential of the microorganisms. Generally, the biodegradation of biodegradable polyester depends on chemical structures and especially on the hydrolysis of the ester bond in the main chain, which favors the formation of monomers and oligomers that are easily absorbed by microorganisms. The enzymatic degradation initiation can be long, indicating that the microbial flora requires a period of acclimation to produce enzymes that are capable of hydrolyzing the polymeric chain ${ }^{[13,14]}$. Wang et al. ${ }^{[15]}$ evaluated the biodegradability of films that were produced with PBAT and observed that the films lost 5\% mass after 18 days in activated mud.

The dry mass of the Brazilian ginseng plants in WBF without a bag, with the bottom cut off and with whole bag did not show a difference at 120 days after planting (Table 4). In the whole BBF and PE bags, the dry mass of the plants dropped to $42 \%$ and $64 \%$, respectively, as compared to the samples without a bag, indicating that the development of the Brazilian ginseng plants could have been disrupted by the wrapping.

The seedlings that developed in the PE bag had twisted and deformed roots due to the lack of space for proper development because the bag remained whole throughout the entire study. In the samples that were collected from the treatment with FBP, the bag was nearly biodegraded, and there was no observed deformity in the roots; such deformity could impede the normal development of the plants. Scapim ${ }^{[9]}$ carried out biodegradation tests of ATp and PBAT during 150 days and verified that the loss of mass depended on the quantity of ATp that was present in the polymeric matrix. Films with $20 \%$ starch lost $29.4 \%$ mass, while films with 30 and $40 \%$ ATp lost 65.9 and $70 \%$ mass, respectively.

A total of 240 days after planting in the containers, the WBF and BBF bags were $100 \%$ biodegraded, and the PE bags showed no sign of degradation or fragility; they showed only a few holes on the underside that had been caused by the roots breaking through (Figure 4). The dry mass of the Brazilian ginseng plants from the WBF and BBF bags and the PE without a bag and with the bottom cut off 
Table 4. Average root dry mass of Brazilian ginseng plants 120 days after planting in containers.

\begin{tabular}{cccc}
\hline \multirow{2}{*}{ Film } & \multicolumn{3}{c}{ Dry mass (g.plant ${ }^{-1}$ ) } \\
\cline { 2 - 4 } & No bag & Bottom cut off & Whole bag \\
\hline WBF & $11.9^{\mathrm{a}, \mathrm{B}} \pm(2.4)$ & $17.7^{\mathrm{a}, \mathrm{A}} \pm(5.2)$ & $14.0^{\mathrm{a}, \mathrm{A}} \pm(5.6)$ \\
BBF & $21.3^{\mathrm{a}, \mathrm{A}} \pm(2.6)$ & $12.4^{\mathrm{b}, \mathrm{A}} \pm(3.4)$ & $11.4^{\mathrm{b}, \mathrm{A}} \pm(1.0)$ \\
PE & $20.5^{\mathrm{a}, \mathrm{A}} \pm(3.9)$ & $12.3^{\mathrm{b}, \mathrm{A}} \pm(5.4)$ & $7.4^{\mathrm{b}, \mathrm{A}} \pm(1.8)$ \\
\hline
\end{tabular}

${ }_{\mathrm{a}, \mathrm{b}}$ Averages with different letters in the same line indicate a statistically significant difference at the 0.05 level by the Tukey test. ${ }^{\mathrm{A}, \mathrm{B}}$ Averages with different letters in the same column indicate a statistically significant difference at the 0.05 level by the Tukey test. White biodegradable film (WBF); Black biodegradable film (BBF).

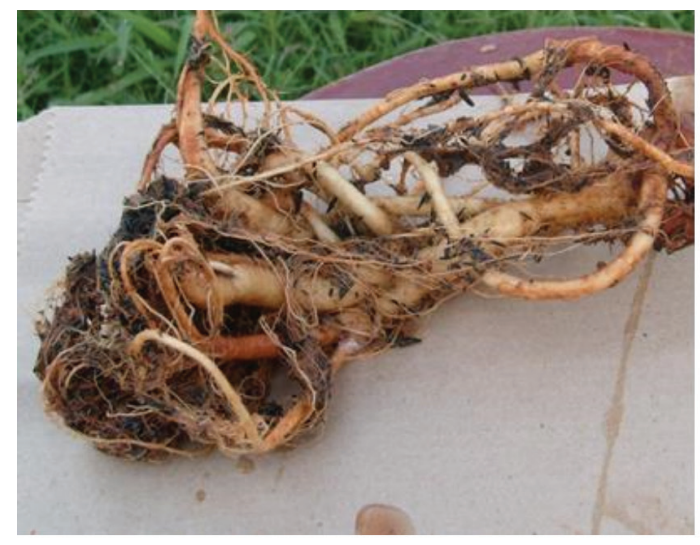

(a)

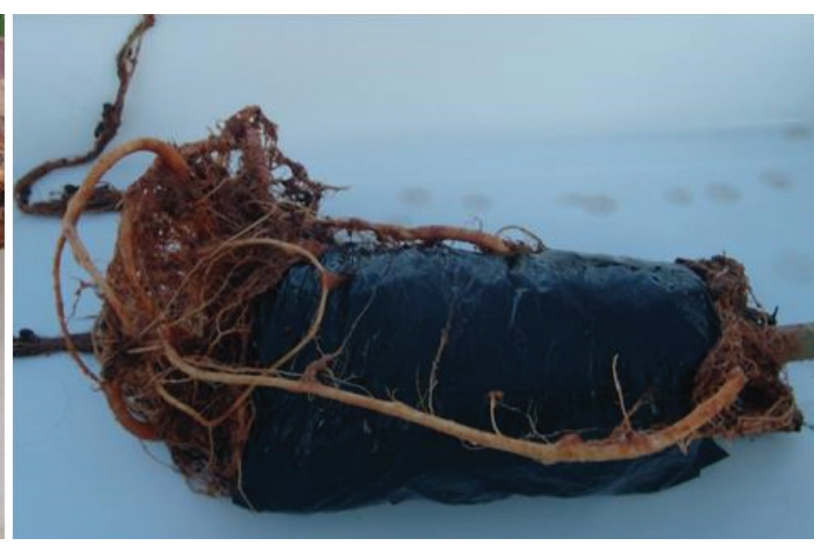

(b)

Figure 4. Evaluation 240 days after planting the BBF (a) and PE (b) bags. Black biodegradable film (BBF).

showed no significant difference between the treatments, with an average of $16.21( \pm 3.5)$ g.plant ${ }^{-1}$.

The dry mass of Brazilian ginseng planted in PE with the entire bag was $23 \%$ and $25 \%$ less than those planted in PE without a bag and PE with the bottom cut off, respectively. Compared to the other treatments, the whole PE also had a lower dry mass: only $27 \%$ of that for the whole WBF and $33.5 \%$ of that for the BBF. The roots of the Brazilian ginseng plants in the whole PE bag grew as much towards the top as outside of the bag by puncturing the sides and the bottom of the bag, indicating that the development of the roots was impaired by the lack of space.

Some authors have studied the development of Brazilian ginseng seedlings in the field and obtained dry mass values that are similar to those found above. Corrêa Júnior et al. ${ }^{[5]}$ produced ginseng seedlings by cuttings and transplanted them into histic dystrophic Ta melanic gleysol, obtaining 12 g.plant ${ }^{-1}$ of dry mass after 240 days; Mattos \& Salis $^{[16]}$ cultivated $P$. glomerata from seeds in Vertisol soil in the Pantanal region of Mato Grosso and obtained a root dry mass of only 6.9 g.plant ${ }^{-1}$ after 374 days from the seed sowing. The authors attributed the low root production to the clayey soil, which could have caused difficult conditions for plant growth.

\section{Conclusions}

The biodegradable bags remained intact throughout the seedling production period (60 days) of Brazilian ginseng. After being transplanted into containers (240 days), the bags were completely biodegraded, and there was no significant difference between the dry mass of these plants and that of plants that were transplanted without the bags. The plants that were cultivated without being removed from the polyethylene bags had root development difficulties, and the polyethylene bags showed no signs of degradation.

The use of biodegradable films is an alternative for the production of bags for seedlings, as these can then be transplanted directly into the soil without removing the bag, reducing the risk of damage to the roots during the moment of transplant.

\section{Acknowledgments}

The authors are grateful for the financial support provided by CAPES, CNPq, and Fundação Araucária.

\section{References}

1. Weng, Y. X.; Jin, Y. J.; Meng, Q. Y.; Wang, L.; Zhang, M. \& Wang, Y. Z. - Polym Test., 32, p.918 (2013). http://dx.doi. org/10.1016/j.polymertesting.2013.05.001

2. Bilck, A. P.; Grossmann, M. V. E. \& Yamashita, F. Polym. Test., 29, p.471 (2010). http://dx.doi.org/10.1016/j. polymertesting.2010.02.007

3. Kijchavengkul, T.; Auras, R.; Rubino, M.; Alvarado, E.; Monteiro, J. R. C. \& Rosales, J. M. - Polym. Degrad. Stab., 95, p.99 (2010). http://dx.doi.org/10.1016/j. polymdegradstab.2009.11.048

4. Briassoulis, D. - Polym. Degrad. Stab., 91, p.1256 (2006). http://dx.doi.org/10.1016/j.polymdegradstab.2005.09.016 
5. Corrêa Jr., C.; Ming, L. C. \& Cortez, D. A. G. - Hortic. Bras., 26, p.393 (2008).

6. American Standard Testing Methods - ASTM. - "Standard test methods for tensile properties of thin plastic sheeting", ASTM, Philadelphia (2002). (ASTM D-882-02).

7. Instituto Agronômico do Paraná - IAPAR. - "Manual de análise química do solo e controle de qualidade", IAPAR, Londrina (2002). (Circular 76).

8. Kijchavengkul, T.; Auras, R.; Rubino, M.; Gouajio, M. \& Fernandez, R. T. - Chemosphere, 71, p.942 (2008). PMid:18262221. http://dx.doi.org/10.1016/j. chemosphere.2007.10.074

9. Scapim, M. R. S. - "Production, characterisation, application and biodegradability of blends films and starch produced by extrusion", Tese de Doutorado, Universidade Estadual de Londrina, Brasil (2009).

10. Chandra, R. \& Rustgi, R. - Prog. Polym. Sci., 23, p.1273 (2008). http://dx.doi.org/10.1016/S0079-6700(97)00039-7

11. Vidal, L. H.; Souza, J. R. P.; Fonseca, E. P. \& Bordin, I. - Hortic. Bras., 24, p.26 (2006). http://dx.doi.org/10.1590/ S0102-05362006000100006
12. Tena-Salcido, C. S.; Rodríguez-González, F. J.; MéndezHernández, M. L. \& Contreras-Esquivel, J. C. - Polym Bull., 60, p.677 (2008). http://dx.doi.org/10.1007/s00289-008-090313. Iovino, R.; Zullo, R.; Rao, M. A.; Cassar, L. \& Gianfreda, L. - Polym. Degrad. Stab., 93, p.147 (2008). http://dx.doi. org/10.1016/j.polymdegradstab.2007.10.011

14. Kim,H. S. \& Kim,H. J. - Polym. Degrad. Stab.,93, p.1544(2008) http://dx.doi.org/10.1016/j.polymdegradstab.2008.05.004

15. Wang, Y. W.; Mo, W.; Yao, H.; Wu, Q.; Chen, J. \& Chen, G. Q. - Polym. Degrad. Stab., 85, p.815 (2004). http://dx.doi. org/10.1016/j.polymdegradstab.2004.02.0116. Mattos, P. P. \& Sallis, S. M. - “Características de Pfaffia glomerata (Sprengel) Pedersen cultivada no Pantanal, sub-região do Paraguai, Corumbá, Mato Grosso do Sul", in: Anais do $4^{\circ}$ Simpósio sobre recursos naturais e socioeconômicos do Pantanal, p.1-7, Corumbá (2004).

Received: Oct. 17, 2013

Revised: Apr. 04, 2014 Accepted: May 05, 2014 